\title{
APPLICATION OF AMMI MODEL IN ZONING OF FAO 400-500 MAIZE HYBRIDS
}

\author{
Bojan Drašković ${ }^{1 \star}$, Veselinka Zečević ${ }^{2}$ Zdravko Hojka ${ }^{1}$, Milomir Filipović ${ }^{3}$, \\ Jelena Srdić, Natalija Kravićs, Vojka Babić ${ }^{3}$
}

\begin{abstract}
Identification of high yielding and stable genotypes is one of the main goals in all breeding programmes. Estimation of hybrids is often aggravated due to the presence of genotype $\mathrm{x}$ environment $(\mathrm{GE})$ interaction. One of the ways to eliminate negative effect of this interaction is the application of reliable statistical models such as AMMI model, which singles out high yielding and stable genotypes that have positive reaction to the improvement of production environments. This research aimed to establish specific maize hybrids interactions in different environments in two years by AMMI analysis. Twelve KWS maize hybrids belonging to FAO 400-500, were examined in two years over eight locations in Vojvodina. The highest yield in both years had the hybrid KWS2 (12.764 kg ha-1). Based on the AMMI1 model, hybrid KWS9 showed the highest stability and adaptability at all locations. According to AMMI2, hybrids KWS1, KWS3 and KWS12, had the highest stability and adaptability, while hybrids KWS2, KWS6, KWS8, KWS9 and KWS10 showed a satisfactory level of stability and it is necessary to pay attention to which locations they have positive interactions in order to be recommended in such regions. Nevertheless, based on the AMMI2, locations Temerin, Kikinda and Zrenjanin, showed similar interaction response, which points out that the number of trial locations could be reduced. Obtained results would contribute to the more precise decision in hybrids recommendation for the certain region, but also in defining further aims in maize breeding.
\end{abstract}

Key words: variety trials, yield stability, Zea mays L.

\section{Introduction}

Maize is produced on about 197 million ha worldwide with an annual production of over one billion tones (FAOSTAT, 2019). It is also estimated that today, about 2,000 products are obtained directly from maize, and indirectly almost 4,000 (Nikolić et al., 2020). These numbers indicate the great importance of maize for nowadays civilization. Thereafter, finding stable maize genotypes is a great challenge for breeders. Besides providing stable maize production for the economy, global on-going climate changes are also a big challenge. Present climate changes will lead to long term temperature rise, which will as a consequence have an increase of evapotranspiration and more often arid periods. Such trends can lead to the widening of existing arid agro ecosystems (Anđelković et al., 2012; Popović et al., 2014). This indicates the high and rising needs for maize and that in breeding besides high yielding hybrids, great attention is necessary to be paid to the stability and adaptability of newly selected genotypes. Modern varieties, due to their high genetic uniformity, could be very sensitive to changeable environmental factors. The creation of a greater number

\footnotetext{
Original Scientific Paper (Originalni naučni rad)

${ }^{1}$ Drašković B, Hojka Z, KWS, Serbia

${ }^{2}$ Zečević V, Institute of Vegetable Crops, Smederevska Palanka, Serbia

${ }^{3}$ Filipović M, Srdić J, Kravić N, Babić V, Maize Research Institute Zemun Polje, Belgrade, Serbia

*e-mail: draskovicbojan1@gmail.com
} 
of genetically different hybrids and their proper recommendation for different environments is the way to overcome such risks (Drašković, 2017), which would provide stable maize production. The application of statistical methods could identify systematic variation within the interaction effect. Thus, in this way is possible to utilise narrow genetic adaptability of genotypes which will enable them to achieve maximal yielding potential in the given environment. In order to estimate the proper region for the production of certain hybrid, a large number of micro trials in production regions should be set (Gauch, 2006; Farshadfar et al., 2011). Such trials encompass test hybrids, hybrids in the process of registration and already registered hybrids. The precision and accuracy of these trials affect the higher significance of each trial. Thus, it is necessary to include replications that raise the precision of experimental estimations of investigated traits (Babić et al., 2019). Nevertheless, the application of modern statistical methods such as Additive main effects and multiplicative interactions (AMMI) contributes to the more reliable selection of superior genotypes that would in the given environment have the best results (Mitrović et al., 2020). Pacheco et al. (2005) found in their research that AMMI and PCA models are very efficient in the identification of the most stable soybean varieties.

GE interaction is a multiplicative source of variance that encompasses the effects of the genotype and environment. Including the interconnection of two major sources of variance (genotype and environment), the precision of results is enhanced, based on which breeders could more efficiently make their decisions (Dimitrijević and Petrović, 2005). With the assistance of computers, complex mathematical calculations based on the decomposition of singular matric values (Singular Value Decomposition-SVD), such as Principal Component Analysis - PCA is, become easily available. There are several disputes in the scientific literature about which multivariate analysis method, out of linear - bilinear models, based on SVD procedure should be favoured. Gauch (2006) favoured the AMMI model because the main effects of genotype, environment and GE interaction should be observed separately due to easier understanding and interpretation of results from the agronomic aspects. Yan et al. (2014) emphasised that prediction accuracy by the correct model selection (AMMI or SREG) should not be overestimated, because replication of genotype estimates in further years could not be expected by the same pattern, due to the most certain genotype/year and genotype/environment/year interactions. Only one genotype is rarely selected because breeding goals are usually contradictory, i.e. several traits of interest are often in negative correlation and rarely one genotype is the best in all of them ideal winner. Gauch (2013) gave simple AMMI model protocol for the analysis of multi-location trials, composed of four steps: (1) analysis of variance, (2) model diagnosis - selection of optimal AMMI model, (3) separation of environments in mega-environments, (4) selection/recommendation of genotypes. It is also considered that stability is justified goal only in one mega-environment, and not in larger number of mega-environments, and noted that many researchers do not take into consideration this key issue.

This research aimed to study the yield and stability of twelve KWS hybrids of $400-500$ FAO maturity groups by GE interaction analysis using the AMMI model. Also, the aim was to select superior genotypes according to yield with the lowest interaction, i.e. stable genotypes which could be recommended for wider production. Based on the obtained results further breeding goals could be defined.

\section{Material and methods}

For this research, a set of 12 KWS hybrids belonging to FAO 400-500 maturity groups is chosen. All the hybrids were in 2014 and 2015 in the process of registration or were pre-commercialized hybrids. Following hybrids were selected: FAO 400: KWS 1, KWS 3, KWS 8 check, KWS 11 and KWS 12; FAO 500: KWS 2, KWS 4, KWS 5 - check, KWS 6, KWS 7, KWS 9 and KWS 10.

Trials were set up according to the Randomized Complete Block Design in three replicates in two years (2014 and 2015), over eight locations (Table 1; Picture 1 and 2). All trials were performed on the same locations in two years, on the nearby plots, so the soil types were the same on the same locations in two years. 
Table 1. List of locations and their symbols

Tabela 1. Lista lokacija i njihovi simboli

\begin{tabular}{lcl}
\hline Location & Symbol & Soil type \\
\hline Bački Maglić & BKM & calcareous chernozem \\
Sombor & SOM & calcareous chernozem \\
Pančevo & PAN & calcareous chernozem \\
Sremska Mitrovica & MIT & calcareous chernozem \\
Zrenjanin & ZRE & chernozem with signs of eu-glay soils \\
Kikinda & KIK & calcareous chernozem/calcareous and non-calcereous grassland chernozem \\
Lovćenac & LOV & calcareous grassland chernozem \\
Temerin & TEM & calcareous chernozem \\
\hline
\end{tabular}

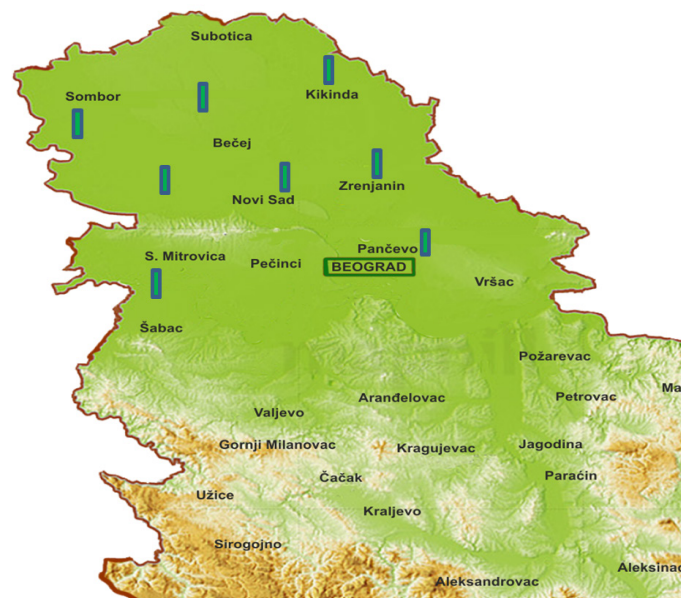

Picture 1. Arrangement of locations on the map of the Republic of Serbia Slika 1. Raspored lokacija na karti Republike Srbije

The elementary plot size was $15.5 \mathrm{~m}^{2}$, while for analyses $7.875 \mathrm{~m}^{2}$ were used. Sowing densities in both years were 71,400 plants per ha. The soil in both years was homogenous, well crumbled and prepared for sowing. Inter - row spacing was $75 \mathrm{~cm}$, while intra row spacing was $19.3 \mathrm{~cm}$. All hybrids were sown in three replicates all containing four rows. Four border rows were sown around each trial. Sowing was performed with the small plot planter, and harvesting with a small plot harvester. Two inner rows were harvested. Cropping practices were standard on all locations in both production years. Dates of emergence, tasselling and silking were noticed during vegetation. Counting of final standing, number of lodged and broken plants was performed before harvest. Grain yield was expressed in $\mathrm{t} \mathrm{ha}^{-1}$ with $14 \%$ of grain moisture.

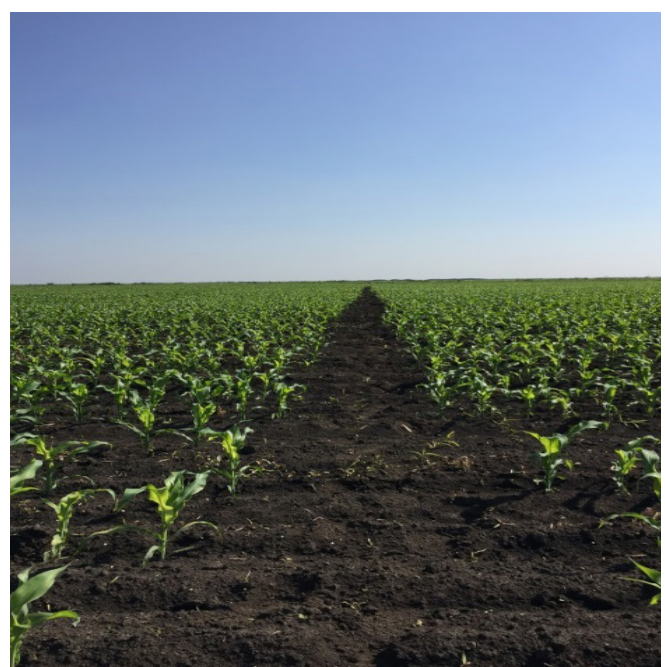

Picture 2. Trials on the location Bački Maglić, 2014. Slika 2. Ogledi na lokaciji Bački Maglić, 2014. 
Table 2. - ANOVA of AMMI model for grain yield of tested maize hybrids

Tabela 2. - ANOVA AMMI modela za prinos zrna ispitivanih hibrida kukurza

\begin{tabular}{|c|c|c|c|c|c|}
\hline Source of variation & DF & SS & MS & $\mathbf{F}$ & $\begin{array}{c}\% \text { of SS } \\
\text { total }\end{array}$ \\
\hline Environment & 15 & 3723.916 & 248.261 & $295.443^{* *}$ & 74.97 \\
\hline Replication & 32 & 25.57 & 0.799 & $1.599 \mathrm{~ns}$ & \\
\hline Genotype & 11 & 301.462 & 27.405 & $4.509^{* *}$ & 6.07 \\
\hline Environment x Genotype & 165 & 620.687 & 3.761 & $3.629^{* *}$ & 12.49 \\
\hline IPCA1 & 25 & 328.96 & & & \\
\hline IPCA2 & 23 & 110.813 & & & \\
\hline Residual & 117 & 180.911 & & & \\
\hline Error & 352 & 295.330 & & & \\
\hline Total & 575 & 4966.969 & & & \\
\hline
\end{tabular}

DF - degree of freedom, SS - sum of squares, MS - mean square; ${ }^{* *}$ - significant at 0.01 probability level; ns - non significant

During trial conduction, the most significant meteorological elements were noticed (maximum, minimum and average air temperature, precipitation, relative humidity)

For the calculation of descriptive statistics and the analysis of variance SPSS program was used (IBM SPSS Statistics 23).

\section{Results and discussion}

Results are presented as summarized for two years 2014 and 2015. A combination of locations and years are used as 16 environments. The influence of the environment, genotype and GE interaction was $74.97 \%$, $6.07 \%$, and $12.49 \%$ respectively. Results of the analysis of variance are following the findings of Gauch and Zobel (1997), Yan at all. (2007), Babić V. et al. (2011). AMMI model was applied in further analysis. A total of 15 IPC (Interaction Principal Components) was obtained by the decomposition of the interactions of the sum of squares. The first interaction axis (IPCA1) explained 52.99\% GE interaction, while the second interaction axis (IPCA2) explained $17.85 \%$. The first and the second axis together encompassed $70.84 \%$ of the sum of squares. SCREE test showed that the first three axes are significant.

AMMI2 leaves the residual of the 190 $\mathrm{kg} \mathrm{ha}^{-1}$, which is $1.64 \%$ of the overall mean
(11576.5 kg ha-1). AMMI analysis results are visually presented on AMMI1 and AMMI2 biplots (Figure 1 and 2). Based on the position of genotypes and environments (Year x Location) on the AMMI1 biplot it could be noticed that the KWS2 hybrid had the highest average yield in two years of experiments. At the same time, the IPCA1 value of KWS2 was slightly higher (0.263), which puts it among relatively unstable hybrids in this research. If we have in mind that it had the highest average yield, then it is clear that this hybrid is on certain locations well adapted. The following hybrids had achieved average yield above the overall means: KWS2, KWS4, KWS6, KWS7, KWS9, KWS10, and KWS12. On contrary following hybrids had average yields below the overall mean: KWS1, KWS3, KWS5, KWS8, KWS11. Similar interaction response across years had locations Temerin, Kikinda and Zrenjanin, i.e. these locations are clearly grouped in both years. Rationalization of the number of test environments could be performed based on this information. The highest contribution of the location interaction had Bački Maglić 2015 (BKM15). It is difficult to accept such a result, due to the fact that this location by the combination of meteorological condition in 2015 did not have pronounced arid conditions like all the other locations. The lowest interaction contribution had Sremska Mitrovica 2014. 


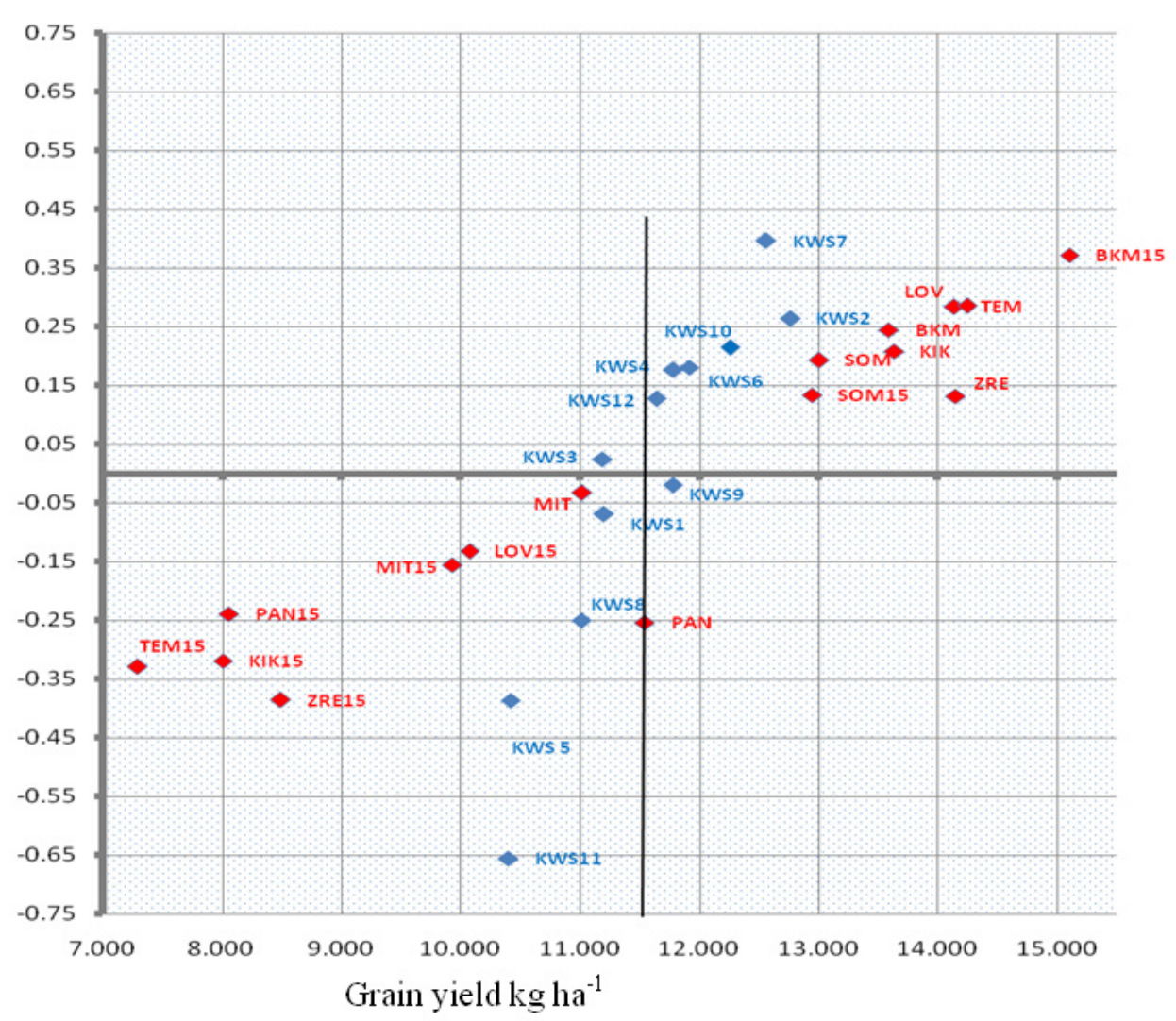

Figure 1. AMMI1 biplot for grain yield of tested maize hybrids

Grafikon 1. AMMI1 biplot za prinos zrna ispitivanih hibrida kukuruza

According to the first interaction axis location, Pančevo in both years had a negative interaction response, while Sombor and Bački Maglić, had a positive response in both years. Hybrids KWS2, KWS7 had specific reaction on the locations Bački Maglić and Sombor, while hybrids KWS1 and KWS9 had a specific interaction with location Sremska Mitrovica. Hybrid KWS9 was the most stable, with the widest adaptation, and could be recommended for almost all locations (Figure 1).

Hybrid KWS9 had in both years, a significantly higher yield compared to the overall mean, and the lowest interaction score $\left(11780 \mathrm{~kg} \mathrm{ha}^{-1}-\right.$ 0.020). Hybrid KWS11 had the lowest average yield and the highest interaction score, so it could be considered as the most unstable, not adapted for any environment. Stable hybrids are also KWS1 and KWS3, who had low IPCA1 scores, and average yield at the level of the overall mean.
As a further contribution to the investigation of the hybrid stability, the AMMI2 biplot is presented with the values of the first two interaction axis (IPCA1 and IPCA2) (Figure 2). The area of the first circle presents the value of the one standard deviation, the area of the second circle value of the two standard deviations and the outer area presents the value of over two standard deviations of the interaction vectors. On the AMMI2 biplot, the first interaction axis explained $52.99 \%$ of the interaction effect, while $17.85 \%$ is explained by the second. In testing experimental hybrids similar ratio IPCA1 - IPCA2 was obtained by Mitrović et al. (2012), Nzuve et al. (2013), Babić M. et al. (2011) and many more. The lowest interaction, within one standard deviation, had hybrids KWS1, KWS3, and KWS12. In the area of two standard deviations were hybrids KWS2, KWS6, KWS8, KWS9, and KWS10. Hybrids 


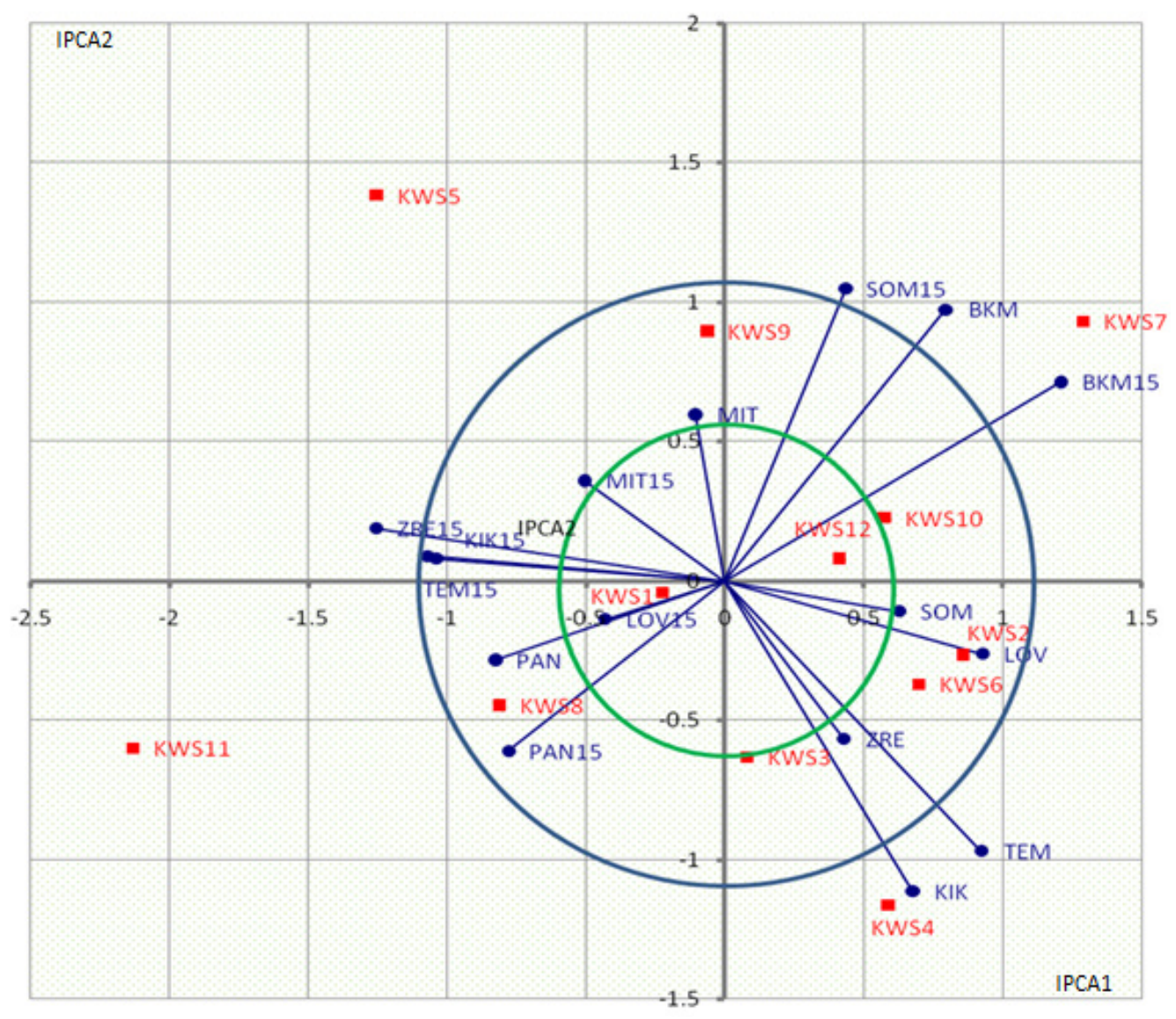

Figure 2. AMMI2 biplot for grain yield of tested maize hybrids Grafikon 2. AMMI2 biplot za prinos zrna ispitivanih hibrida kukuruza

beyond the area of two standard deviations were KWS4, KWS5, KWS7, and KWS11, which indicates that the stability of these hybrids was the lowest.

This paper aimed to obtain reliable information by application of modern statistical models, from two-year trial data, based on which more precise zoning of hybrids could be performed, as well as the definition of mega environments for their testing and production. Maize production could be improved by the precise zoning, identification of genotypes of wide adaptability and stability, as well as hybrids of narrow adaptability with a positive reaction to certain regions (Branković-Radojčić et al., 2018). Based on our research it could be concluded that different hybrids achieved the highest yields on different locations in differ- ent years. Nevertheless, it should be taken into consideration that this research was performed in two meteorologically different years, so obtained data point to the fact that this research should be continued on a larger number of environments with the aim of obtaining reliable data for precise zoning and defining mega environments for maize production in the investigated region of Serbia.

\section{Conclusion}

Out of twelve analysed hybrids, the highest yield in two years had hybrid KWS2 $(12764 \mathrm{~kg}$ $\mathrm{ha}^{-1}$ ) and the lowest KWS11 (10401 kg ha-1). The overall mean of the trial was $11164 \mathrm{~kg}$ $\mathrm{ha}^{-1}$. Analysis of variance showed significance of the genotypes, environments and their 
interactions in both years, so the application of AMMI analysis was appropriate. Based on the analysis of variance of the AMMI model, mid squares of hybrids and locations, as well as their interactions were significant.

In the total sum of squares for both years, environments, genotype, and interaction participate with $74.97 \%, 6.07 \%$, and $12.49 \%$, respectively, so the certain amount of the valuable information contained in the GE interaction would be lost if only analysis of variance was applied.

By the application of the AMMI model, the first interaction axis explained $52.99 \%$ and the second $17.95 \%$ of the GE interaction. IPCA1 and IPCA2, together, explained 79.55\%.

Based on the AMMI1 model hybrid KWS9, with an average yield above the overall mean, showed the highest stability.

AMMI2 model pointed out KWS1, KWS3 and KWS12 hybrids as the most stable. Hybrids KWS2, KWS6, KWS8, KWS9, and KWS10, also showed a satisfactory level of stability. But it is necessary to pay attention to which locations they have positive interactions so they could be recommended for production in such regions.

This research could have a significant scientific and professional contribution to the understanding of stability and adaptability of maize hybrids and significance for proper hybrid zoning and achieving genetic yielding and quality potential.

\section{References}

Anđelković V, Ignjatović-Mićić D, Vančetović J, Babić M. (2012): Integrated approach to improve drought tolerance in maize. Selekcija i semenarstvo, 18(2): 1-18.

Babić M, Babić V, Delić N, Anđelković V, Prodanović S (2011): The comparison of stability parameters according to the Finlay-Wilkinson, Eberhart-Russell and AMMI model. Selekcija i semenarstvo, 17(2): 35-40.

Babić M, Čanak P, Vujošević B, Babić V, Stanisavljević D (2019): Significance of field trials data cleaning process for making more reliable breeder decisions. Selekcija i semenarstvo 25(2): 23-30.
Babić V, Babić M, Ivanović M, Filipović M (2011): Pattern in interaction in the maize yield trial. Journal of agricultural sciences, 56(2): 101-110.

Branković-Radojčić D, Babić V, Girek Z, Zivanović T, Radojčić A, Filipović M, Srdić J (2018): Evaluation of Maize Grain Yield and Yield Stability by AMMI Analysis, Genetika, 50 (3): 1067-1080.

Dimitrijević M, Petrović S (2005): Genetika populacije (adaptabilnost i stabilnost genotipa). Poljoprivredni fakultet u Novom Sadu i Naučni institut za ratastvo i povrtarstvo, Novi Sad, s: 47-50.

Drašković B (2017): Procena stabilnosti prinosa KWS genotipova kukuruza. Master rad. Fakultet za biofarming, Bačka Topola.

FAOSTAT (2019): FAO Statistical Database. (http//:faostat.fao/org)

Farshadfar E, Mahmodi N, Yaghotipoor A (2011): AMMI stability value and simultaneous estimation of yield and yield stability in bread wheat (Triticum aestivum L.). Australian Journal of Crop Science, 5(13): 1837-1844.

Gauch HG (2013): A Simple Protocol for AMMI Analysis of Yield Trials. Crop Science, 53 (5): 1860-1869.

Gauch HGJr (2006): Statistical analysis of yield trials by AMMI and GGE. Crop Science, 46: $1488-1500$.

Gauch HGJr, Zobel RW (1997): Identifying mega-environments and targeting genotypes. Crop Science, 37: 311-326.

Mitrović B, Drašković B, Stanisavljević D, Perišić M, Čanak P, Mitrović I, Tančić-Živanović S (2020): Environmental modeling of interaction variance for grain yield of medium early maturity maize hybrids. Genetika, 52(1): 367-378.

Mitrović B, Stanisavljević D, Treskić S, Stojaković M, Ivanović M, Bekavac G, Rajković M (2012): Evaluation of experimental maize hybrids tested in multi-location trials using AMMI and GGE biplot analyses. Turkish Journal of Field Crops, 17(1): 35-40.

Nikolić V, Žilić S, Radosavljević M, Simić M. (2020): The role of maize hybrids in current trends of bioethanol production. Selekcija i semenarstvo, 26(2): 21-29. 
Nzuve F, Githiri S, Mukunaya DM, Gethi J (2013): Analysis of Genotype x Environment Interaction for Grain Yield in Maize Hybrids. Journal of Agricultural Science, 5(11): 75-85.

Pacheco RM, Duarte JB, Vencovsky R, Pinheiro JB, Oliveira AB (2005): Use of Supplementary Genotypes in AMMI Analysis. Theoretical and Applied Genetics, 110: 812-818.
Popović A, Babić V, Kravić N, Sečanski M, Prodanović S (2014): Breeding for plant adaptations and agricultural measures in response to climatic changes in Serbia. Selekcija i semenarstvo, 20(2): 59-72.

Yan W (2014): Crop Variety Trials: Data Management and Analysis. Wiley-Blackwell.

Yan W, Kang MS, Ma B, Woods S, Cornelius PL (2007): GGE biplot vs. AMMI analysis of genotype-by-environment data. Crop Science, 47: 643-655. 


\title{
REJONIZACIJA HIBRIDA KUKURUZA FAO 400-500 PRIMENOM AMMI MODELA
}

\author{
Bojan Drašković, Veselinka Zečević, Zdravko Hojka, Milomir Filipović, \\ Jelena Srdić, Natalija Kravić, Vojka Babić
}

\begin{abstract}
Sažetak
Identifikacija visoko prinosnih i stabilnih genotipova jedan je od vodećih ciljeva u svim oplemenjivačkim programima. Pravilna procena hibrida je često veoma otežana usled prisustva interakcije genotip/spoljašnja sredina. Jedan od načina da se eliminišu negativne posledice interakcije je da se primenom pouzdanih statističkih modela, kao što je AMMI model, izdvoje stabilni, visoko prinosni genotipovi, koji pozitivo reaguju na poboljšanje uslova u kojima se gaje. Cilj ovog rada bio je da se metodom AMMI analize pronađu i utvrde specifične interakcije hibrida kukuruza u različitim sredinama u dve godine istraživanja. Odabrano je 12 KWS hibrida kukuruza FAO 400-500, koji su ispitivani u dve godine na šest lokaliteta u Vojvodini. Najveći prinos u obe godine ispitivanja imao je hibrid KWS2 (12.764 kg ha-1). Na osnovu AMMI1 modela hibrid KWS9 je pokazao najveću stabilnost i adaptabilnost na svim lokacijama. Analizom AMMI2 biplota utvrđeno je da hibridi KWS1, KWS3 i KWS12 pokazuju najveću stabilnost i adaptabilnost, dok hibridi KWS2, KWS6, KWS8, KWS9 i KWS10 pokazuju zadovoljavajući nivo stabilnosti i potrebno je obratiti pažnju sa kojim lokacijama ostvaruju pozitivne interakcije i u tim regionima ih preporučivati. Takođe na osnovu AMMI2 biplota, lokacije Temerin, Kikinda i Zrenjanin su pokazale vrlo sličan interakcijski odgovor, što ukazuje na mogućnost smanjenja broja lokacija za izvođenje ogleda. Rezultati dobijeni ovim istraživanjem će doprineti preciznijem i kvalitetnijem odlučivanju prilikom izbora hibrida koji će se gajiti u određenom regionu, ali i definisanju daljih pravaca u oplemenjivanju kukuruza.
\end{abstract}

Ključne reči: sortni ogledi, stabilnost prinosa, Zea mays L.

Primljen: 20.04.2021.

Prihvaćen: 21.05.2021. 
